\title{
Erratum to: The effect of local bone mineral density on the rate of mechanical failure after surgical treatment of distal radius fractures: a prospective multicentre cohort study including 249 patients
}

\author{
Daniel Rikli • Joerg Goldhahn · Kurt Käch • \\ Christine Voigt $\cdot$ Andreas Platz $\cdot$ Beate Hanson
}

Published online: 23 April 2015

(C) Springer-Verlag Berlin Heidelberg 2015

Erratum to: Arch Orthop Trauma Surg (2015)

135:201-207

DOI 10.1007/s00402-014-2130-5

In the original publication of this article, the author names were transposed: the first names were presented as last names and the last names as first names. Moreover, in the author addresses footnote of the PDF version of the original article, the first names were presented as last names and the last names reduced to first initials.

The online version of the original article can be found under doi:10.1007/s00402-014-2130-5.

\section{Rikli $(\bowtie)$}

Department of Traumatology, University Hospital Basel,

Spitalstrasse 21, 4031 Basel, Switzerland

e-mail: daniel.rikli@usb.ch

\section{J. Goldhahn}

Institute for Biomechanics, ETH Zurich, Vladimir-Prelog-Weg

1-5/10, 8093 Zurich, Switzerland

K. Käch

Department of Trauma Surgery, Kantonsspital Winterthur,

Brauerstrasse 15, 8401 Winterthur, Switzerland

C. Voigt

Department of Trauma and Reconstructive Surgery,

Friederikenstift Hannover, Humboldstrasse 5, 30169 Hannover, Germany

\section{A. Platz}

Department of General, Hand, and Trauma Surgery, Stadtspital

Triemli, Birmensdorferstrasse 497, 8063 Zurich, Switzerland

B. Hanson

AO Clinical Investigation and Documentation, AO Foundation,

Stettbachstrasse 6, 8600 Dübendorf, Switzerland
The author line should read as follows:

Daniel Rikli · Joerg Goldhahn · Kurt Käch ·

Christine Voigt · Andreas Platz · Beate Hanson 